\title{
Analisis level makroskopis, mikroskopis dan simbolik mahasiswa dalam memahami elektrokimia
}

\author{
Wati Sukmawati \\ Department of Pharmacy and Sains, Universitas Muhammadiyah Prof. DR. HAMKA. \\ Jalan Delima No. II/IV, Klender, Jakarta, 13460, Indonesia. \\ * Coressponding Author. E-mail: wati_sukmawati@uhamka.ac.id \\ Received: 5 October 2019; Revised: 14 November 2019; Accepted: 18 November 2019
}

\begin{abstract}
Abstrak
Penelitian ini bertujuan untuk mengetahui tingkat pemahaman mahasiswa dilihat dari aspek makroskopis, mikroskopis dan simbolik dalam memahami konsep. Fenomena pembelajaran kimia yang ditemukan hampir selalu terfokus pada tingkat makroskopik berupa rumus dan angka, sedangkan tingkat yang sering luput dari pengematan adalah tingkat mikroskopik dan simbolik seperti penyajian diagram dan proses reaksi kimia. Salah satu sifat dari ilmu kimia adalah cenderung bersifat abstrak dan kompleks, seperti proses terjadinya reaksi elektrolisis dimana terjadi pergerakan partikel yang tidak dapat diamati oleh mata sehingga sering terjadi miskonsepsi dalam memahami konsep kimia. Penelitian ini menggunakan metode eksperimen semu dengan pendekantan kuantitatif dilakukan pada mahasiswa semester satu sebanyak 40 orang di prodi Farmasi Universitas Muhammadiyah Prof. DR. Hamka. Sampel penelitian ini diambil secara purposive random sampling dengan kuisioner. Berdasarkan hasil penelitian diperoleh hasil pemahaman mahasiswa pada konsep elektrokimia dilihat dari level makroskopis sebesar 72.75\% kategori baik, level mikroskopis sebesar $66.25 \%$ kategori baik dan simbolik adalah $70 \%$ kategori baik. Sehingga dapat disimpulkan bahwa pembelajaran dengan aspek makroskopis, mikroskopis, simbolik dapat menanamkan konsep secara utuh.
\end{abstract}

Kata Kunci: makroskopis, mikroskopis, simbolik, elektrokimia.

\section{Analysis of macroscopic, microscopic and symbolic levels of students in understanding electrochemistry}

\begin{abstract}
This research aims to find out the students' comprehension from the macroscopic, microscopic, and symbolic aspects of the concept. The phenomenon of chemistry learning that is found almost focused on the macroscopic level in the form of formulas and numbers, while the level that often missed in some observation is microscopic and symbolic levels; such as diagramming and chemical reaction processes. One of the characteristics of chemistry tends to be abstract and complex, as the process of electrolysis reaction in which the particle movement can't be observed so that misconceptions often occur in understanding chemical concepts. This study uses quasi-experimental methods with quantitative approach conducted by 40 semester students in the first semester of Pharmacy at the University of Muhammadiyah Prof. DR. Hamka. The research sample was taken by purposive random sampling with a questionnaire. Based on the result, the students' comprehension of the electrochemistry concept have 72,75\% good category in macroscopic level, $66,25 \%$ good category in microscopic level, and $70 \%$ good category in symbolic. So, it can be concluded that learning with macroscopic, microscopic, and symbolic could fulfill the concept perfectly.
\end{abstract}

Keywords: macroscopic, microscopic, symbolic, electrochemistry

How to Cite: Sukmawati, W. (2019). Analisis level makroskopis, mikroskopis dan simbolik mahasiswa dalam memahami elektrokimia. Jurnal Inovasi Pendidikan IPA, 5(2), 195-204. doi:https://doi.org/10.21831/jipi.v5i2.27517

do https://doi.org/10.21831/jipi.v5i2.27517

\section{PENDAHULUAN}

Ilmu kimia memiliki peranan yang sangat penting bagi kehidupan masyarakat, karena manusia tidak lepas dari penggunaan zat-zat kimia dalam kehidupan sehari-hari. Kimia merupakan salah satu rumpun Ilmu Pengetahuan Alam (IPA). Ilmu kimia merupakan ilmu yang mempelajari fakta, konsep, dan prinsip kimia. Dalam 


\section{Jurnal Inovasi Pendidikan IPA, 5 (2), 2019 - 196}

Wati Sukmawati

ilmu kimia dipelajari tentang proses, produk, dan sikap.

Kimia dilihat dari segi proses meliputi kemampuan dalam hal mengamati, mengukur, mengelompokkan, menyampaikan pertanyaan, merangkai hipotesis dan lain sebagainya. Sedangkan ilmu kimia dilihat dari aspek sikap meliputi sikap peduli terhadap lingkungan, sikap ingin tahu, ulet, jujur, sabar, kritis, tekun, disiplin, cermat, memperhatikan keselamatan kerja, dan bekerja sama. Beberapa keterampilan tersebut merupakan keterampilan proses, dan aspek sikap yang disebutkan merupakan sikap yang dimiliki para ilmuwan dan dapat dikatakan sebagai sikap ilmiah.

Dalam melakukan pembelajaran kimia juga seharusnya memperhatikan beberapa hal dari karakteristik dari ilmu kimia itu sendiri, baik dari aspek proses, produk dan sikap. Hanya saja kenyataan yang ditemukan di lapangan pembelajaran kimia hanya berorientasi pada produk tanpa memperhatikan aspek sikap dan proses. Sehingga, kimia selama ini menjadi salah satu ilmu yang dianggap sulit. Untuk mengatasi permasalahan tersebut, ilmu kimia perlu disampaikan secara lengkap baik aspek proses, sikap dan hasil sehingga siswa dapat mempelajari ilmu kimia dengan mudah.

Pemahaman konsep kimia dasar bagi mahasiswa tingkat satu sangat diperlukan, karena menjadi dasar dalam memahami ilmu kimia dasar dengan baik sebagai bekal mempelajari matakuliah kefarmasian lainnya. Topik-topik esensial pada matakuliah kimia dasar terutama yang diperoleh mahasiswa farmasi adalah sel elektrokimia, termokimia, kesetimbangan kimia, stiokiometri, struktur atom dan molekul, serta laju reaksi,dan kimia inti. Namun berdasarkan hasil pengamatan tim teaching selama melakukan perkuliahan di kelas menunjukan bahwa "perhatian mahasiswa cukup rendah dan banyak terjadi miskonsepsi" terutama pada materi yang penuh dengan perhitungan. Terjadinya miskonsepsi mahasiswa disebabkan sebagian besar dikarenakan mahasiswa sulit memahami konsep ilmu kimia bersifat abstrak.

Walaupun penilaian pemahaman kimia secara makroskopik merupakan yang menjadi fokus kimia, alangkah baiknya jika pemahaman tersebut dikuatkan dengan pemahaman dari segi representasi level submikroskopik dan simbolik. Hal ini dilakukan dengan tujuan mahasiswa mampu memahami konsep kimia secara menyeluruh baik dari aspek makroskopis, mikroskopis dan simbolik.
Elektrokimia merupakan salah satu konsep dari ilmu kimia dan salah satu pokok bahasan yang dipelajari oleh mahasiswa farmasi matakuliah kimia dasar. Salah satu sifat dari ilmu kimia adalah cenderung bersifat abstrak dan kompleks, seperti proses terjadinya reaksi elektrolisis dimana terjadi pergerakan partikel yang tidak dapat diamati oleh mata. Dengan sifat yang abstrak maka diperlukan cara untuk mempelajari kimia secara menyeluruh. Selain itu dalam mempelajari suatu konsep yang kompleks dan abstrak tersebut menurut (Coll, 2008; Jansoon, Coll, \& Somsook, 2009) diperlukan tiga level representasi meliputi, level makroskopik, submikroskopik, dan simbolik. Bodner dan Domin (2000) menyatakan bahwa pengembangan model mental diperlukan dalam memprediksi, menguji ide baru dan memecahkan masalah dalam pembelajaran kimia. Sehingga untuk menjelaskan konsep ilmu kimia diperlukan pemahaman baik dari level makroskopis, submikroskopis dan simbolik.

Selain itu dijelaskan pula bahwa level makroskopik merupakan aspek yang menjelaskan sesuatu yang terjadi dalam kehiupan sehari-hari, sedangkan level submikroskopik menjelaskan kenyadian kehidupan sehari-hari dari segi mikroskopis, sedangkan level simbolik merupakan menjelaskan fenomena nyata yang dinyatakan dalam bentuk gambar. Dapat diperlihatkan pada Gambar 1.

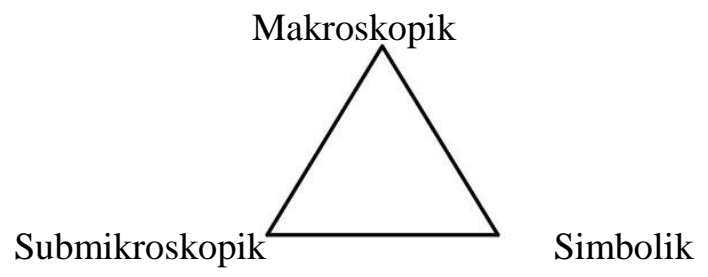

Gambar 1. Level Representasi Kimia

Dalam mempelajari ilmu kimia tidak dapat mengesampingkan ketiga representasi tersebut. Baik untuk mahasiswa yang baru belajar kimia maupun yang sudah lama. Pembelajaran kimia sebaiknya menekankan pemahamannya pada level submikroskopis karena ini adalah esensi dari ilmu kimia. Ilmu kimia menjelaskan tentang struktur, susunan, sifat-sifat, dan perubahan materi, serta energi yang terlibat dalam perubahan tersebut. Sebagian pembahasan kimia mengarah pada aspek makroskopis, perubahan materi, seperti sifat materi dan energi.

Ketiga level representasi tersebut harus dimiliki mahasiswa dalam mempelajari ilmu kimia. Ketiga level representasi itu harus dapat dikuasai oleh mahasiswa agar dapat memahami 


\section{Jurnal Inovasi Pendidikan IPA, 5 (2), 2019 - 197}

Wati Sukmawati

ilmu kimia secara mendalam dan menyeluruh (Chittleborough, Treagust, \& Mocerino, 2002; Treagust, Chittleborough, \& Mamiala, 2003). Adapun ketiga level represtasi yang dimaksud adalah makroskopis, submikroskopis dan simbolik (Mansouri, 2007). Representasi makroskopik, dapat diartikan bahwa representasi kimia yang diperoleh melalui pengamatan dari fenomena yang dapat dilihat (terlihat) dan dirasakan oleh indera atau bisa menjadi pengalaman yang diperoleh sehari-hari peserta didik (岡戸順一 et al., 2003). Sifat dari representasi makroskopik adalah nyata dan dapat diamati langsung. Contoh: warna, bentuk suhu, dan lain-lain. Mahasiswa bisa melakukan pengamatan atau kegiatan lab di berbagai sumber informasi dan dapat disampaikan berupa laporan, kegiatan diskusi, kegiatan presentasi, dan sebagainya. Representasi mikroskopik merupakan level representasi yang abstrak memberikan penjelasan pada tingkat partikulat. Submikroskopik erat kaitannya dengan model teoritis yang mendasari penjelasan dinamika tingkat partikel (atom, molekul, dan ion). Mode representasi pada tingkat ini dapat mengekspresikan mulai dari yang sederhana misalnya menggunakan teknologi komputer, menggunakan kata-kata, gambar dua dimensi, gambar tiga dimensi baik diam maupun bergerak (animasi) atau simulasi. Level simbolik (atau ikon) representasi adalah representasi untuk mengidentifikasi identitas (misalnya zatzat yang terlibat dalam reaksi kimia) dengan menggunakan bahasa simbolis kualitatif dan kuantitatif, seperti rumus kimia, diagram, gambar, persamaan, stoikiometri, dan perhitungan matematis" (岡戸順一 et al., 2003).

Pelajaran kimia bagi sebagian siswa merupakan pelajaran yang dianggap sulit untuk dipahami, kurang menarik, dan tidak relevan. Salah satu penyebabnya adalah kurang minat dan motivasi siswa, siswa merasa terpaksa atau hanya sebagai suatu kewajiban. Selain itu, karakteristik dari konsep-konsep ilmu kimia yang bersifat abstrak juga menyebabkan kimia sulit untuk dipelajari. Salah satu materi kimia yang bersifat abstrak dan dianggap sulit oleh sebagian besar siswa adalah materi elektrokimia.

Berdasarkan materi elektrokimia, hasil penelitian sebelumnya menunjukkan bahwa tingkat pemahaman level makroskopis, mikroskopis, dan simbolik mahasiswa materi elektrokimia mahasiswa masih menggunakan model mental dengan inisial dalam menjelaskan fenomena reaksi pada level mikroskopik sebesar 74,3 \% (Supriadi, Ibnu, \& Yahmin, 2018). Mahasiswa dapat memahami materi elektrokimia hanya pada tingkat makroskopis saja. Penelitian sebelumnya menunjukkan bahwa tingkat pemahaman siswa SMA di Indonesia dan di Jepang terhadap materi elektrokimia hanya sebesar 40\% (Rahayu, Treagust, Chandrasegaran, Kita, \& Ibnu, 2011). Kriteria tingkat pemahaman konsep yang telah dimodifikasi yaitu paham konsep, paham sebagian dengan spesifik miskonsepsi, miskonsepsi dan tidak paham konsep (Yörük, Morgil, \& Seçken, 2010).

Materi elektrokimia merupakan materi yang cenderung sulit dipahami oleh mahasiswa secara menyeluruh dari aspek makroskopis, mikroskopis dan simbolik. Berdasarkan hasil beberapa penelitian tentang pemahaman mahasiswa terhadap konsep elektrokimia menunjukkan bahwa secara umum mahasiswa hanya mampu berada pada tingkat representasi makroskopik, sedangkan tingkat representasi submikroskopik dan simbolik masih lemah.

Peneliti bermaksud untuk mengkaji tingkat pemahaman mahasiswa pada tingkat makroskopis, submikroskopis, dan simbolik terhadap konsep elektrokimia. Penelitian bertujuan untuk mengetahui tingkat pemahaman mahasiswa dilihat dari level makroskopis, submikroskopis dan simbolik pada materi elektrokimia. Seberapa besar mahasiswa mampu memahami konsep kimia khususnya konsep elektrokimia secara utuh baik dari aspek makroskopis mikroskopis dan simbolik. Pada penelitian ini juga akan membahas seberapa pentingnya penelitian ini dilakukan, permasalahan yang diangkat dalam penelitian ini dan solusi yang ditawarkan.

\section{METODE}

Penelitian ini menggunakan metode eksperimen semu dengan pendekatan kuantitatif. Sedangkan populasi dalam penelitian ini adalah seluruh mahasiswa semester satu yang mengambil mata kulia kimia dasar. Sampel yang digunakan, diambil dengan teknik purposive random sampling atau secara acak.

Penelitian ini menggunakan metode penelitian quasi eksperimen (Setiawan, Fajaruddin, \& Andini, 2019) yaitu nonequivalent kontrol group design untuk mengetahui tingkat kemampuan mahasiswa dilihat dari level makroskopis, mikroskopis, dan simbolik pada materi elektrokimia. Sedangkan metode deskriptif digunakan untuk mendeskripsikan pemahaman mahasiswa pada materi elektrokimia dilihat dari level makroskopis, mikroskopis, dan simbolik serta miskonsepsi yang dialami mahasiswa. 


\section{Jurnal Inovasi Pendidikan IPA, 5 (2), 2019 - 198}

Wati Sukmawati

Data yang diperoleh dari hasil pengujian pemahaman mahasiwa tersebut lalu dilakukan analisis lebih lanjut menggunakan analisis deskriptif kualitatif dan kuantitatif. Data yang dianalisis dengan cara kualitatif berupa data yang didapatkan dari saran yang diperoleh dari ahli, ujicoba pendahuluan dan tanggapan mahasiswa terhadap pemahaman konsepnya. Sedangkan untuk analasis data kuantitatif dilakukan untuk mengolah hasil ujicoba instrumen soal sebagai indikator hasil belajar yang diberikan serta pengolahan angket yang diberikan.

Data hasil skor pada angket penilaian pemahaman konsep kimia yang diperoleh dari proses pembelajaran yang dilakukan oleh mahasiswa, data pemahaman konsep tersebut akan ditampilkan dalam bentuk persentase baik persentase kelayakan bahan ajar. Selain itu data yang dituangkan juga data hasil pengukuran pemahaman mahasiswa dan hasil belajar yang telah dilakukan oleh mahasiswa.

Penelitian ini dilakukan di Universitas Muhammadiyah Prof. Dr. Hamka Fakultas Farmasi dan Sains Program Studi Farmasi. Subjek penelitian ini adalah mahasiswa semester satu sebanyak 160 orang yang telah mendapatkan materi elektrokimia dan sampel diambil secara purposive sampling sebanyak 40 orang. Partisipan dipilih berdasarkan tingkat pemahamannya, yaitu kategori sangat baik (81-100), baik (61-80), cukup (41-60), kurang (21-40), dan sangat kurang (0-20).

Proses pengambilan data adalah dengan menggunakan instrumen berupa soal pilihan ganda sebanyak 30 butir soal yang memunculkan level makroskopis, mikroskopis dan simbolik masing-masing 10 soal materi elektrokimia. Soal terlebih dahulu dilakukan uji validasi dengan jenis validasi content validity (validasi isi) dan uji realibilitas untuk menguji konsistensi. Dari data penelitian diperoleh informasi bahwa instrumen yang digunakan dinyatakan valid karena menunjukkan nilai CVR 0,36 > 0,29 dan realibilitas diuji menggunakan SPSS dengan nilai Cronbach's Alpha 0,837 > 0,60 maka dinyatakan reliable (Persamaan 1). Menurut Persamaan $1 \mathrm{r}_{11}$ merupakan reliabilitas instrumen, $\mathrm{n}$ adalah banyaknya butir soal, $\mathrm{S}_{\mathrm{i}}{ }^{2}$ adalah jumlah varians skor tiap butir, dan $\mathrm{S}_{\mathrm{t}}{ }^{2}$ adalah varians skor total

$$
\left.r_{11}=\left[\frac{n}{n-1}\right]\left[1-\frac{S_{i}{ }^{2}}{S_{t}{ }^{2}}\right] \ldots \ldots \ldots \ldots \ldots \ldots \ldots . . . . . .1\right)
$$

Data yang diperoleh selanjutnya diolah dengan proses analisis secara deskriptif dengan tujuan untuk mengetahui kemampuan pemaham- an mahasiswa dalam memahami soal yang diberikan baik dari aspek submikroskopis, makroskopis, maupun simbolik.

Selain analisis deskriptif, soal yang dikeluarkan perlu dilakukan analisis statistik berupa uji prasyarat berupa uji normalitas dan homogenitas. Uji normalitas menggunakan uji Kolmogorov-Smirnov serta digunakan juga uji homogenitas menggunakan uji Levene. Selain itu untuk menambah analsis data dilakukan juga uji hipotesis dengan menggunakan uji Anacova.

\section{HASIL DAN PEMBAHASAN}

\section{Analisis Level Makroskopis}

Level pemahaman submikroskopis merupakan suatu konsep yang abstrak berupa partikel yang dapat digunakan dalam menjelaskan peristiwa reaksi kimia. Contohnya peristiwa ionisasi dimana di dalam air Natrium Clorida terurai menjadi ion-ionnya.

Pemahaman level makroskopik adalah pemahaman kimia yang berdasarkan hasil pengamatan yang diperoleh dari lingkungan lalu dicerna oleh indra baik secara langsung atau tak langsung. Pengamatan yang dilakukan biasanya tidak luput dari segala aktivitas yang dilakukan sehari-hari yang ditemukan di lapangan maupun yang ditemukan saat melekukan percobaan di lab.

Berdasarkan hasil penelitian tentang representasi makroskopik siswa terhadap sistem dan prinsip kerja sel elektrokimia dapat ditarik kesimpulan bahwa sebagian besar mahasiswa dapat merepresentasikan sel elektrokimia pada tingkat makroskopik dengan benar ditinjau dari cara perangkaian beserta komponen dalam sel volta dan sel elektrolisis, kutub elektrode, fungsi jembatan garam. Semua mahasiswa mampu mereprentasikan prinsip kerja dan perangkaian sel elektrokimia dengan benar. Namun, setiap mahasiswa memberikan representasi yang bervariasi dalam memahami prinsip kerja jembatan garam. Hal ini timbul karena mahasiswa tidak memahami prinsip kerja sel elektrokimia secara submikroskopik dengan benar. Sebagian besar mahasiswa dapat merepresentasikan kutub elektrode pada sel volta dan sel elektrolisis dengan benar.

Berdasarkan penelitian yang diambil dari instrument yang telah disebar dan diolah didapatkan data berupa sebaran tingkat pemahaman mahasiswa pada materi elektrokimia khusus level makroskopis adalah sebagian besar mahasiswa masuk kedalam kelompok baik sebesar $40 \%$, 


\section{Jurnal Inovasi Pendidikan IPA, 5 (2), 2019 - 199}

Wati Sukmawati

$28 \%$ sangat baik, $25 \%$ cukup dan $7 \%$ kurang, hal ini berarti bahwa sebagian besar mahasiswa dapat memahami materi elektrokimia pada tingkat makroskopik dengan benar ditinjau dari jawaban mahasiswa.

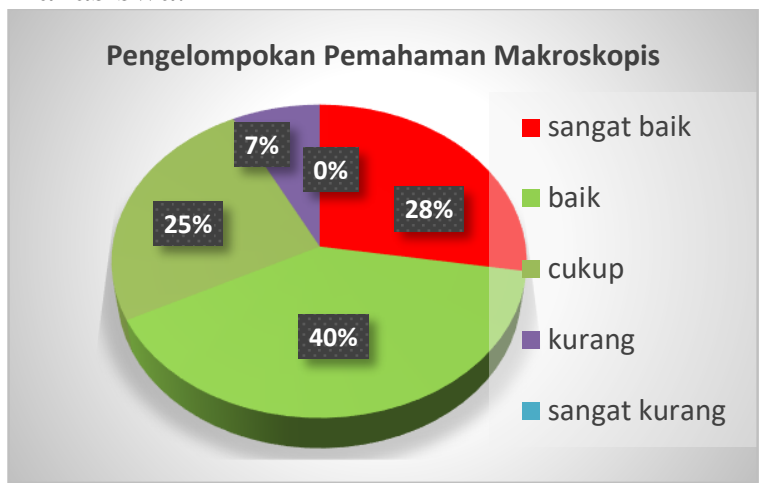

Gambar 2. Pengelompokan Pemahaman Makroskopis

Berdasarkan data yang didapat, semua mahasiswa mampu memahami prinsip kerja elektrokimia dengan benar. Kondisi tersebut sesuai dengan penelitian yang telah dilakukan sebelumnya yang menyatakan bahwa hanya sedikit siswa yang mengalami kesulitan dalam memahami prinsip dasar sel elektrokimia dan fungsi komponen. Berdasarkan temuan berupa mahasiswa yang masih mengalami kesulitan dengan mengaplikasikan konsep kimia dalam kehidupan sehari-hari maka seyogyanya pembelajaran kimia tidak hanya ditujukan pada penguasaan konsep saja namun penting untuk diintegrasikan didalam konteks kehidupan (Shwartz, Ben-Zvi, \& Hofstein, 2009) (Schwarz et al., 2009) juga yang berkaitan dengan lingkungan (Farida, Liliasari, Sopandi, \& Widyantoro, 2017; Kozma \& Russel, 2007).

Pemahaman mahasiswa dalam mengaitkan ketiga level representasi kimia tersebut merupakan gambaran dari pemahaman representasi kimia mahasiswa tersebut. Selama melakukan proses pembelajaran hakikatnya seseorang sedang melakukan proses mental. Dalam pelaksanaannya kegiatan proses mental berjalan berdasarkan pengetahuan awal, pengalaman, dan penguasaan konsepnya yang dimiliki setiap mahasiswa.

Dalam pelaksanaannya proses mental akan menghasilkan model metal berupa hasil pemahaman yang dimiliki oleh mahasiswa selama mereka belajar dan dan mampu menyelesaikan permasalahan yang muncul pada pembelajaran tersebut. Saat mahasiswa mampu memahami konsep kimia secara utuh dengan mengaitkan ketiga level representasi kimia maka mahasiwa dapat dikatakan mampu memahami konsep kimia secara utuh. Sedangkan jika mahasiswa tidak mampu mengaitkan ketiga level tersebut maka dapat dikatakan bahwa pemahaman yang dimiliki mahasiswa tersebut tidak utuh dan rentan untuk menimbulkan miskonsepsi.

Model mental yang dijelaskan diatas dapat dijadikan suatu informasi bagi dosen. Dosen dapat mengetahui dan dapat menganalisis sejauh mana pemahaman konsep kimia dilihat dari kemampuan mahasiswa dalam memahami konsep kimia secara utuh berdasarkan multipel representasi kimia atau masih belum mengaitkannya. Jika mahasiswa mampu mengaitkannya maka ia dikatakan paham konsep kimia secara utuh jika tidak maka dikatakan pemahaman konsep tak utuh dan menghasilkan miskonsepsi. Dengan penjelasan tersebut terlihat seberapa pentingnya penanaman model mental dengan mengaitkan ketiga level representasi kimia dengan baik dalam proses pembelajaran kimia.

Jika proses mental dengan mengaitkan ketiga level representasi kimia dilakukan dalam pembelajaran maka miskonsepsi yang timbul pada mahasiswapun dapat diidentifikasi. Miskonsepsi yang terjadi pada mahasiswa sebaiknya perlu dihindarkan, hal ini akan mempengaruhi ke pemahaman konsep kimia berikutnya. Miskonsepsi yang muncul di kalangan mahasiswa merupakan sumber masalah yang harus segera diselesaikan. Dengan demikian segala bentuk miskonsepsi yang muncul dari proses pembelajaran yang dilakukan sebaiknya dapat dimonitor oleh dosen sehingga perlu penanganan yang tepat dan tidak berkelanjutan dan dapat memperbaiki konsep pemahaman mahasiswa yang baik dan benar. Mahasiswa yang mampu memahami konsep kimia dengan baik, maka ia akan lebih mudah menerima konsep baru dengan baik dan benar.

\section{Analisis Level Mikroskopis}

Aspek mikroskopis dapat diartikan sebagai kemamuan mahasiswa dalam memvisualisasikan sesuatu yang bersifat abstrak hal tersebut memerlukan kemampuan yang baik sehingga dapat memahami konsep dengan baik dan terhindar dari miskonsepsi. Miskonsepsi dalam mempelajari suatu konsep menjadi hal yang penting untuk dihindari, sehingga diperlukan kemampuan visualisasi dari suatu konsep yang abstrak sebaiknya harus dimiliki oleh setiap mahasiswa.

Secara umum, mahasiswa mendapat kesulitan dalam merepresentasikan aliran ion dan elektron secara submikroskopik, sehingga timbul 


\section{Jurnal Inovasi Pendidikan IPA, 5 (2), 2019 - 200}

Wati Sukmawati

berbagai kesalahan pemahaman. Mahasiswa dapat merepresentasikan secara submikroskopik reaksi yang terjadi pada anode dan katode, partikel yang ada dalam larutan serta arah aliran partikel dengan menggunakan gambaran submikroskopik walaupun beberapa mahasiswa memberikan representasi submikroskopik yang salah. Siswa juga mampu menghitung potensial sel volta dan sel elektrolisis dengan benar dan menghubungkannya dengan prinsip kerja sel. Hubungan antar tingkat representasi yang jarang ditunjukkan oleh siswa adalah hubungan representasi tingkat makroskopik, submikroskopik dan hubungan antara ketiga tingkat representasi. Secara umum mahasiswa dapat menghubungkan antar tingkat representasinya, tetapi setiap siswa memiliki pemahaman yang bervariasi sehingga mengakibatkan muncul representasi yang bervariasi pula

Berdasarkan penelitian diperoleh data adalah tingkat pemahaman mahasiswa dalam pemahaman level mikroskopis pada materi elektrokimia adalah $20 \%$ sangat baik, $32 \%$ baik, $33 \%$ cukup dan $15 \%$ kurang. Berdasarkan data tersebut tingkat pemahaman mikroskopik mahasiswa pada pemahaman elektrokimia secara umum dapat disimpulkan bahwa dalam menentukan gambaran mikroskopik elektrokimia tergolong rendah. Penyebab rendahnya gambaran mikroskopis tersebut dikarenakan mahasiswa menganggap bahwa molekul yang terlarut dalam peristiwa elektrolisis masih dalam bentuk molekulnya tidak terurai menjadi ionnya. Akibatnya dalam menjawab pilihan gambar submikroskopik, mahasiswa memilih jawaban yang salah. Hal ini dapat dilihat pada Gambar 3.

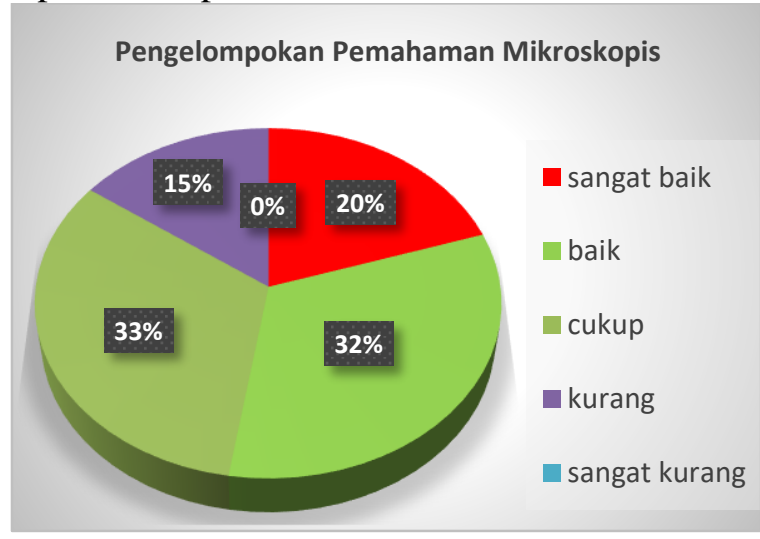

Gambar 3. Pengelompokan Pemahaman submikroskopis

Selain itu, faktor yang menyebabkan rendahnya pemahaman submikroskopik mahasiswa adalah karena pembelajaran kimia yang selama ini lebih menonjolkan aspek makroskopik dan simbolik saja sedangkan aspek mikroskopik diabaikan. Akibatnya mahasiswa menafsirkan sendiri pemahaman dari aspek submikroskopik tersebut sesuai kemampuan yang mereka miliki. Pernyataan tersebut sesuai dengan penelitian sebelumnya yang dilakukan oleh Mocerino pemahaman mikroskopis yang diterima oleh mahasiswa itu berdasarkan kemampuan yang dimiliki dalam menangkap penjelasan yang diperolehnya (Chittleborough, Treagust, Mamiala, \& Mocerino, 2005; Chittleborough \& Treagust, 2009; Treagust et al., 2003). Selain itu pemahaman konsep yang salah juga bisa disebabkan mahasiswa tidak mampu memvisualisasikan struktur submikroskopis, hal ini sesuai pernyataan Tasker dan Dalton bahwa kesalahan konsep yang sering dialami oleh mahasiswa juga dipengaruhi oleh keterbatasan mahasiswa dalam mengkonkritkan sesuatu yang bersifat abstrak (Tasker \& Dalton, 2006).

Keterbatasan mahasiswa tersebut sesuai dengan pernyataan bahwa pembelajaran dengan memperhatikan pendekatan submikroskopis dapat meningkatkan kemampuan konseptual mahasiswa. Hal ini dikarenakan dengan adanya penjelasan mikroskopis mahasiswa mampu menghubungkan gambaran mikroskopis dengan konsep yang utuh.

\section{Analisis Level Simbolik}

Aspek Simbolik adalah gambar-gambar dan lambang yang membantu menjelaskan konsep yang abstrak. Contoh aspek simbolik adalah Asam Klorida memiliki lambang $\mathrm{HCl}$, dan masih banyak lagi contoh yang lainnya.

Level simbolik merupakan aspek ilmu kimia yang berupa simbol atau tulisan baik secara kualitatif maupun kuantitatif. Seperti rumus kimia suatu senyawa, simbol, diagram, gambar, persamaan reaksi, perhitungan dan sebagainya. Taber (2009) menjelaskan bahwa level simbolik menjelaskan sesuatu yang berupa simbol seperti persamaan kimia yang sesuai dengan aturan penulisannya.

Level simbolik juga mencakup tentang penjelasan kualitatif yang digunakan untuk menjelaskan lebih jauh yang ada pada level submikroskopik. Penjelasan yang digunakan itu berupa singkatan (shorthand) dari makna yang terkandung pada level submikroskopik, selain itu dapat juga digunakan untuk menjelaskan secara kuantitatif makna yang ada pada level submikroskopis.

Ilmu kimia lebih sering menggunakan lambang matematika, rumus dan persamaan untuk memperlihatkan hubungan level makroskopik, 
level submikroskopik dan level simbolik. Seharusnya penguasaan level simbolik akan lebih mudah untuk mahasiswa dalam menguasai pengetahuan level makroskopik dan pemahaman level submikroskopik. Namun hal tersebut tidak sesuai dengan data yang diperoleh secara signifikan tidak berbeda pada level simbolik.

Berdasarkan penelitian, diperoleh data tingkat pemahaman mahasiswa dalam pemahaman level simbolik pada materi elektrokimia adalah $22 \%$ sangat $38 \%$ baik, $22 \%$ cukup dan $10 \%$ kurang. Sebagian besar mahasiswa sudah mampu menuliskan reaksi elektrolisis yang dilihat dari jawaban mahasiswa pada Gambar 4.

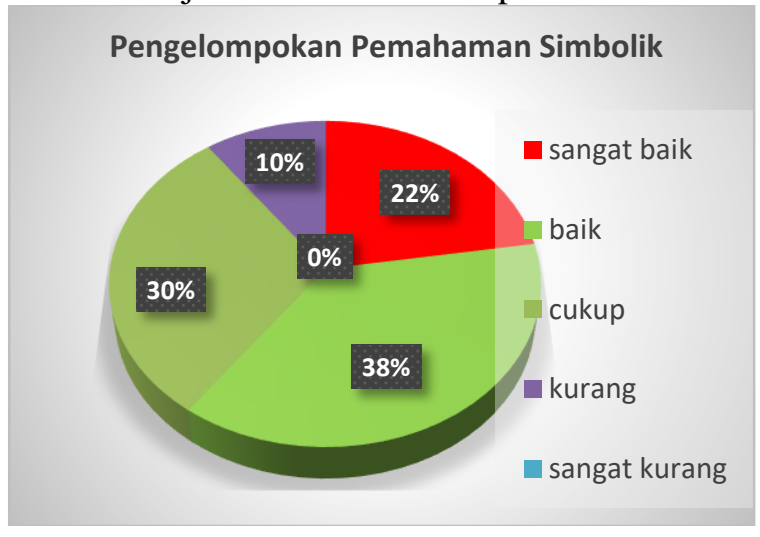

Gambar 4. Pengelompokan Pemahaman Simbolik

Namun masih ada yang belum bisa memahami reaksi elektrolisis sehingga mahasiswa mengalami kesalahan dalam memahami konsep elektrolisis. Selain itu masih banyak mahasiswa yang masih kesulitan menuliskan rumus kimia suatu senyawa sehingga mereka juga salah dalam memahami reaksi. Namun secara keseluruhan hampir semua mahasiswa mampu memahami elektrokimia dari aspek simbolik dengan baik sehingga dari aspek simbolik dapat mengurangi kesalahan dalam pemahaman elektrokimia.

Berdasarkan pernyataan tersebut dapat disimpulkan bahwa pemberian materi kimia berupa hafalan dapat menyebabkab kesalahan pemahaman dalam mengembangkan konsep dasar yang dikuasainya untuk meyelesaikan berbagai macam pengembangan soal.

\section{Rerata Analisis Makroskopis, Mikroskopis, dan Simbolik}

Berdasarkan analisis level makroskopis, mikroskopis dan simbolik diatas, dapat ditarik kesimpulan berupa rerata pemahaman ketiga level tersebut pada materi elektrokimia diperoleh data pemahaman level makroskopik $72,75 \%$ dengan kategori baik, pemahaman level mikro- skopis adalah 66,25\% dengan kategori baik dan pemahaman pada level simbolik adalah $70 \%$ dengan kategori baik. Berdasarkan data tersebut secara keseluruhan data menunjukkan tingkat pemahaman mahasiswa pada ketiga level tersebut adalah baik. Dapat dilihat pada Gambar 5.

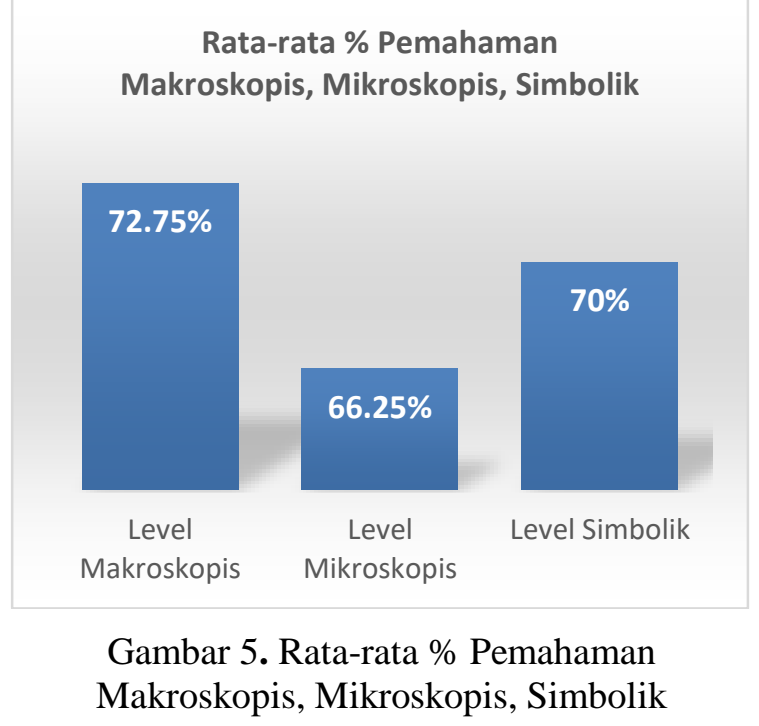

Hubungan antar tingkat representasi yang jarang ditunjukkan oleh mahasiswa adalah hubungan representasi tingkat makroskopik, submikroskopik dan hubungan antara ketiga tingkat representasi. mahasiswa merasa kesulitan untuk menghubungkan antara representasi makroskopik dengan submikroskopiknya. Seluruh mahasiswa mampu memahami sistem dan prinsip kerja sel elektrokimia secara makroskopik. Namun, setiap mahasiswa merasa kesulitan ketika merepresentasikan sistem dan prinsip kerja sel elektrokimia secara submikroskopik. Bahkan, ada beberapa siswa meralat jawabannya karena representasi makroskopik yang telah dimiliki tidak sejalan dengan representasi submikroskopiknya, sehingga menimbulkan konsepsi yang bervariasi. Hal ini disebabkan siswa hanya mampu memahami sel elektrokimia secara makroskopik tanpa mengetahui bagaimana sel elektrokimia bekerja secara submikroskopik.

Berdasarkan beberapa hasil yang ditemukan pada penelitian yang dilakukan sebelumnya oleh peneliti lain, dalam penelitian inipun ditemukan kasus yang sama yaitu masih rendahnya pemahaman mahasiswa jika dilihat dari level submikroskopis dibandingkan dengan level makroskopis dan simbolik. Dalam pembelajaran yang berlangsung juga masih belum ditemukan model pembelajaran yang mengaitkan ketiga level tersebut. Bahkan untuk level simbolik yang cukup banyak dimunculkanpun hanya berupa simbolisasi, persamaan reaksi dan rumus dalam 


\section{Jurnal Inovasi Pendidikan IPA, 5 (2), 2019 - 202}

Wati Sukmawati

perhitungan kimia (Chittleborough \& Treagust, 2007).

Jika disadari pemahaman kimia dari aspek submikroskopis jika dipahami dengan baik oleh peserta didik hal ini akan menjadi kekuatan yang potensial untuk memahami konse kimia dengan baik karena sudah mampu memvisualisasikan sesuatu yang abstrak. Namun kenyataannya level submikroskopis ini masih lemah dipahami oleh peserta didik karena selama pembelajaran sedikit tersentuh bahkan mungkin tidak tersentuh sehingga yang diajarkan hanya level makroskopis dan simbolik saja (Wright dalam Davidowiz \& Chittleborough, 2009).

Berdasarkan persentase level makroskopis mahasiswa paling tinggi dan yang paling rendah adalah level mikroskopis. Hal ini dikarenakan mahasiswa masih mengalami kesulitan dalam menerjemahkan apa yang mereka lihat dari aspek makoskopik dan simbolik ke dalam aspek mikroskopik. Pemberian tiga level representasi kimia kepada mahasiswa secara bersamaan kepada mahasiswa dapat menjadikan memori otak mahasiswa bekerja melampaui batas dan jika tidak dilakukan akan menimbulkan miskonsepsi (Sirhan, 2007).

Berdasarkan hasil penelitian, ditemukan beberapa miskonsepsi yang ditunjukkan oleh mahasiswa. Miskonsepsi ini terjadi karena mahasiswa tidak memahami sistem dan prinsip kerja sel elektrokimia dengan benar, sehingga menimbulkan berbagai alternatif konsepsi. Miskonsepsi yang ditemukan peneliti akan dibandingkan dengan hasil penelitian terdahulu yang relevan dengan penelitian yang pernah ditemukan oleh peneliti lain.

Terdapat beberapa temuan yang didapatkan terkait pemahaman yang dimiliki oleh mahasiswa, setiap mahasiswa memiliki kecenderungan pemahaman yang berbeda pada ketiga level representasi kimia tersebut. Sehingga, hal tersebut menjadi dasar bahwa pemahaman ketiga level dan keterkaitannya satu sama lain harus disajikan dalam pembelajaran kimia. Jika hal tersebut terwujud maka tingkat pemahaman mahasiswa terhadap konsep kimia semakin baik.

Hubungan multipel representasi kimia sangat memegang peranan penting atas pemahaman konsep yang akan diperoleh mahasiswa dalam pembelajaran di kelas. Untuk melaksanakan pembelajaran yang mengedepankan ketiga level tersebut, banyak dilakukan dengan berbagai cara baik di kelas maupun di lab dengan bantuan peralatan lainnya. Mahasiswa farmasi sangat penting untuk memahami konsep-konsep dasar kimia, hal ini dikarenakan menjadi bekal atau prasyarat untuk memahami konsep ilmu kefarmasian lainnya dan mungkin juga kemampuan representasi mahasiswa dapat diterapkan untuk konsep lainnya. Dengan demikian, pemahaman multipel representasi dalam konsep kimia perlu diterapkan dalam pembelajaran kimia.sehingga konsep yang diterima utuk dan terhindar dari miskonsepsi.

Pada kasus kemampuan mahasiswa dalam melakukan pemecahan masalah, pemahaman representasi jika dilihat dari kemampuan seseorang merupakan cara seseorang dalam memecahkan masalah sesuai dengan kemampuan dasar yang dipahami seseorang dan ada dalam pikirannya (model mental), sedangkan representasi dari luar diri seseorang berhubungan kemampuan seseorang mengingat kembali apa yang ia pahami untuk menjelaskan masalah yang baru dengan pemahaman yang telah ia miliki sebelumnya.

Berdasarkan data yang diperoleh penjelasan konsep reaksi elektroda pada level submikroskopis. Level submikroskopis merupakan level yang membutuhkan pemikiran ditingkat molekuler atau atomik. Oleh karena itu konsep tersebut sering disebut sebagai konsep abstrak dimana oleh beberapa peneliti diakui sebagai alasan mengapa ilmu kimia sulit dipahami mahasiswa. Adanya penjelasan yang menggambarkan level sub mikroskopis tersebut dapat membantu mahasiswa dalam memahami konsep abstrak menjadi nyata.

Dalam menjelaskan konsep reaksi elektroda pada level simbolik. Level simbolik merupakan hal yang penting bagi mahasiswa karena level tersebut mampu menyederhanakan konsep kimia yang cukup rumit. Dari beberapa sumber yang dapat diperoleh mahasiswa sebagian besar menjelaskan konsep kimia dalam bentuk simbolik. Diharapkan berdasarkan aspek simbolik yang mahasiswa pahami tersebut diharapkan daat juga memahami dari aspek lainnya sehingga mahasiswa dapat memelajari konsep kimia secara utuh dan menyeluruh.

\section{SIMPULAN}

Simpulan yang ditemukan dari penelitian yang telah dilaksanakan dengan judul analisis level makroskopis, mikroskopis, dan simbolik mahasiswa dalam memahami elektrokimia dapat disimpulkan bahwa kemampuan pemahaman level makroskopis, mikroskopis dan simbolik dalam memahami konsep elektrokimia sudah baik, hanya saja masih banyak ditemukan mahasiswa mengalami kesulitan memahami secara 
mikroskopis pada konsep elektrokimia. Hal ini akan berpengaruh besar terhadap pemahaman konsep elektrokimia secara menyeluruh karena dapat menimbulkan kesalahan dalam memahami konsep.

Bentuk hubungan yang sering ditunjukkan oleh mahasiswa adalah hubungan representasi tingkat submikroskopik-simbolik dan makroskopik-simbolik. Hubungan yang jarang ditunjukkan oleh mahasiswa adalah hubungan representasi makroskopik-submikroskopik dan hubungan ketiga tingkat representasi. Selain itu, mahasiswa memiliki pola pikir yang bervariasi dalam memahami konsep elektrokimia.

\section{DAFTAR PUSTAKA}

Bodner, M. G., \& Domin, D. S. (2000). Mental models: The role of representations in problem solving in chemistry. University Chemistry Education, 4(1), 24-30.

Chittleborough, G. D., \& Treagust, D. F. (2009). Why models are advantageous to learning science. Educación Química, 20(1), 12$17 . \quad$ https://doi.org/10.1016/S0187893X(18)30003-X

Chittleborough, G. D., Treagust, D. F., Mamiala, T. L., \& Mocerino, M. (2005). Students' perceptions of the role of models in the process of science and in the process of learning. Research in Science \& Technological Education, 23(2), 195-212. https://doi.org/10.1080/026351405002664 84

Chittleborough, G. D., Treagust, D. F., \& Mocerino, M. (2002). Constraints to the development of first year university chemistry students' mental models of chemical phenomena. Focusing on the Student, 43-50.

Coll, R. K. (2008). Chemistry learners' preferred mental models for chemical bonding. Journal of Turkish Science Education (TUSED), 5(1). Retrieved from http://www.tused.org/index.php/tused/ho me

Farida, I., Liliasari, L., Sopandi, W., \& Widyantoro, D. (2017). A web-based model to enhance competency in the interconnection of multiple levels of representation for pre-service teachers, 359-362.

https://doi.org/10.1201/978131516657584
Jansoon, N., Coll, R. K., \& Somsook, E. (2009). Understanding mental models of dilution in Thai students. International Journal of Environmental and Science Education, 4(2), 147-168.

Kozma, R., \& Russel, J. (2007). Representational competence's profile of pre-service chemistry teachers in chemical problem solving in science and science education. Visualization in Science Education, 9-27.

Mansouri, F. (2007). Cultural diversity as an educational advantage. Ethos, 15(3), 1518.

Rahayu, S., Treagust, D. F., Chandrasegaran, A. L., Kita, M., \& Ibnu, S. (2011). Assessment of electrochemical concepts: a comparative study involving senior highschool students in Indonesia and Japan. Research in Science \& Technological Education, 29(2), 169-188. https://doi.org/10.1080/02635143.2010.53 6949

Schwarz, C. V., Reiser, B. J., Davis, E. A., Kenyon, L., Achér, A., Fortus, D., ... Krajcik, J. (2009). Developing a learning progression for scientific modeling: Making scientific modeling accessible and meaningful for learners. Journal of Research in Science Teaching, 46(6), 632654. https://doi.org/10.1002/tea.20311

Setiawan, A., Fajaruddin, S., \& Andini, D. W. (2019). Development an honesty and discipline assessment instrument in the integrated thematic learning at elementary school. Jurnal Prima Edukasia, 7(1), 919.

https://doi.org/10.21831/jpe.v7i1.23117

Shwartz, Y., Ben-Zvi, R., \& Hofstein, A. (2009). Chemical Literacy: What Does This Mean to Scientists and School Teachers? Journal of Chemical Education, 83(10), 1557. https://doi.org/10.1021/ed083p1557

Sirhan, G. (2007). Learning difficulties in chemistry: An overview. The Journal of Turkish Science Education, 4(2), 2-20.

Supriadi, S., Ibnu, S., \& Yahmin, Y. (2018). Analisis model mental mahasiswa pendidikan kimia dalam memahami berbagai jenis reaksi kimia. Jurnal Pijar MIPA, 13(1), 1. https://doi.org/10.29303/jpm.v13i1.433

Tasker, R., \& Dalton, R. (2006). Research into practice: visualisation of the molecular 


\section{Jurnal Inovasi Pendidikan IPA, 5 (2), 2019 - 204}

Wati Sukmawati

world using animations. Chem. Educ. Res. Pract., 7(2), 141-159. https://doi.org/10.1039/B5RP90020D

Treagust, D., Chittleborough, G., \& Mamiala, T. (2003). The role of submicroscopic and symbolic representations in chemical explanations. International Journal of Science Education, 25(11), 1353-1368. https://doi.org/10.1080/095006903200007 0306

Yörük, N., Morgil, I., \& Seçken, N. (2010). The effects of science, technology, society, environment (STSE) interactions on teaching chemistry. Natural Science, 02(12), 1417-1424. https://doi.org/10.4236/ns.2010.212173

岡戸順一, 艾斌, 巴山玉蓮, 櫻井尚子, 藤原佳 典, \& 星旦二. (2003). 主観的健康感を中 心とした在宅高齢者における健康関連 指標に関する共分散構造分析 (特集 人 々の健康を支援する方法). 総合都市研 究, (81), 19-30. 